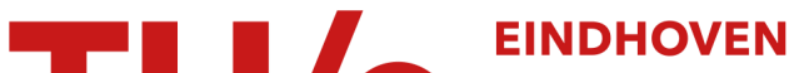 \\ UNIVERSITY OF \\ TECHNOLOGY
}

\section{Bauschinger effect in thin metal films on compliant substrates}

Citation for published version (APA):

Hoefnagels, J. P. M., \& Vlassak, J. J. (2007). Bauschinger effect in thin metal films on compliant substrates. In E. E. Gdoutos (Ed.), Experimental Analysis of Nano and Engineering Materials and Structures (pp. 63-64). https://doi.org/10.1007/978-1-4020-6239-1_30

DOI:

10.1007/978-1-4020-6239-1_30

Document status and date:

Published: 01/01/2007

Document Version:

Accepted manuscript including changes made at the peer-review stage

Please check the document version of this publication:

- A submitted manuscript is the version of the article upon submission and before peer-review. There can be important differences between the submitted version and the official published version of record. People interested in the research are advised to contact the author for the final version of the publication, or visit the $\mathrm{DOI}$ to the publisher's website.

- The final author version and the galley proof are versions of the publication after peer review.

- The final published version features the final layout of the paper including the volume, issue and page numbers.

Link to publication

\section{General rights}

Copyright and moral rights for the publications made accessible in the public portal are retained by the authors and/or other copyright owners and it is a condition of accessing publications that users recognise and abide by the legal requirements associated with these rights.

- Users may download and print one copy of any publication from the public portal for the purpose of private study or research.

- You may not further distribute the material or use it for any profit-making activity or commercial gain

- You may freely distribute the URL identifying the publication in the public portal.

If the publication is distributed under the terms of Article $25 \mathrm{fa}$ of the Dutch Copyright Act, indicated by the "Taverne" license above, please follow below link for the End User Agreement:

www.tue.nl/taverne

Take down policy

If you believe that this document breaches copyright please contact us at:

openaccess@tue.nl

providing details and we will investigate your claim. 


\title{
BAUSCHINGER EFFECT IN THIN METAL FILMS ON COMPLIANT SUBSTRATES
}

\author{
J.P.M. Hoefnagels ${ }^{1)}$ and J.J. Vlassak ${ }^{2)}$ \\ ${ }^{1)}$ Eindhoven University of Technology, Department of Mechanical Engineering, PO Box 513, \\ $5600 \mathrm{MB}$, Eindhoven, The Netherlands \\ ${ }^{2)}$ Division of Engineering and Applied Sciences, Harvard University, 29 Oxford Street, \\ Cambridge, MA 02138-2901, USA \\ e-mail: j.p.m.hoefnagels@tue.nl, tel: +31-40-2475894, fax: +31-40-2447355
}

\section{Summary}

Flexible electronic devices such as flexible displays and solar cells draw more and more attention from the industry. In these devices, the functionality is delivered by small-scale structures consisting of thin metal lines and other materials that are integrated on a compliant (e.g. polymer) substrate to make the device flexible. A major concern is reliability, since the smallscale structures with features on the order of micrometers or below are highly fragile, however, they are subjected to large thermo-mechanical loads during manufacturing and use. Although a growing literature exists on rupture and buckling of thin metal films on polymer substrates, see for instance Hutchinson and Suo [1], many mechanical issues of flexible electronics have not been studied in depth. In this project, one such issue, the Bauschinger effect of thin metal films bonded to a compliant substrate, will be studied in more detail, because the Bauschinger effect appears to be a particularly important issue in flexible electronics applications where the device is subjected to multiple strain cycles.
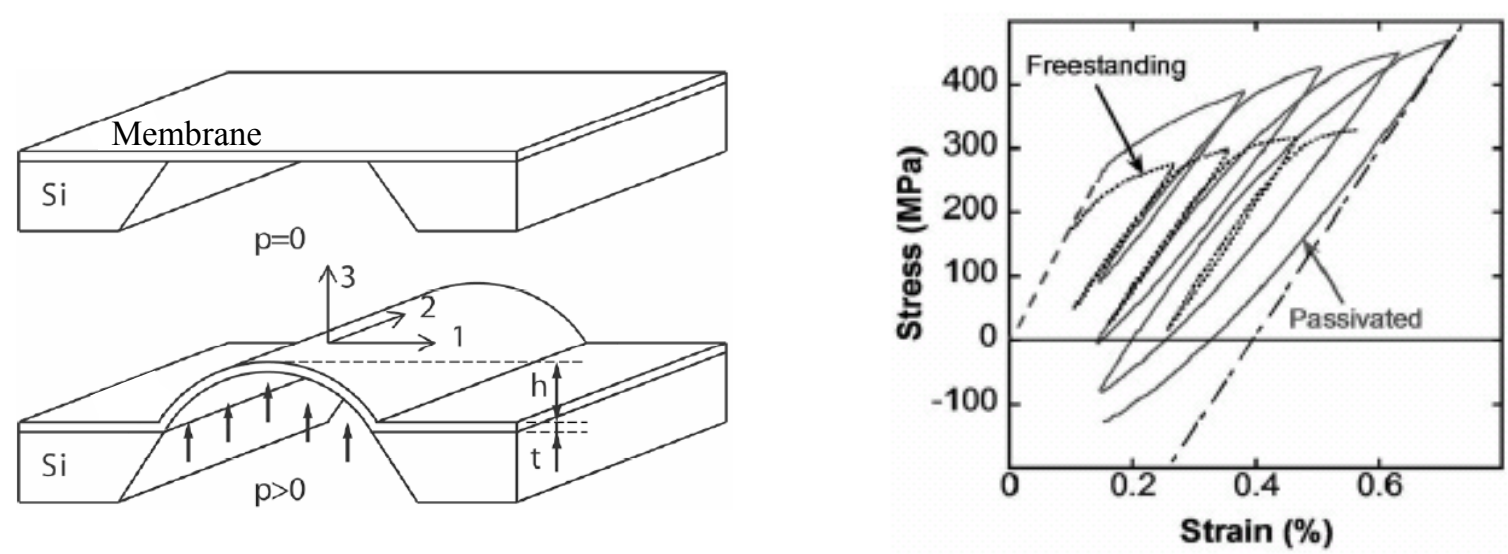

FIGURE 1. (a) Schematic of the plane-strain bulge test to determine the stress-strain curves of thin membrane, where the membrane may be a single material layer or a stack of multiple material layers. (b) Stress-strain curves of a freestanding $0.6 \mu \mathrm{m} \mathrm{Cu}$ film and the same $\mathrm{Cu}$ film passivated by a hard SiN film. Both figures taken from Ref. [2].

We will study the effect of weak interfaces experimentally by means of the plane-strain bulge test technique. which was developed within the Vlassak group at Harvard University, see e.g. Ref. [3]. In this technique, rectangular micromachined membranes fabricated out of the material 
of interest are deflected by applying a pressure to the membrane, see Fig. 1(a). The stress-strain curve of the membrane material is readily determined from the deflection, $h$, of the membrane. Previously, this technique has been used to measure stress-strain curves of metal films as thin as $100 \mathrm{~nm}$ [4]. It should be noted that the membrane does not need to be a single material layer, but can in fact by any multi-layer stack of thin material films.

Xiang and Vlassak used a double-layer stack consisting of a sputter deposited $\mathrm{Cu}$ thin film adhered on a hard SiN film to alternately drive the $\mathrm{Cu}$ film in tension and compression [2], see Fig 1(b). They observed that the $\mathrm{Cu}$ film exhibit an unusual Bauschinger effect with reverse flow already occurring on unloading. This behavior was explained by the built-up of a dislocation density at the $\mathrm{Cu}-\mathrm{SiN}$ interface that was assumed to be impenetrable to dislocation movement, i.e. the interface was said to be 'fully passivated'. On the other hand, the freestanding $\mathrm{Cu}$ thin film, showed little or no reverse flows when the film is fully unloaded, see Fig. 1(b).

While the effect on plasticity in metallic films with a free surface versus films with a strong interface on a hard and stiff substrate may be understood, it is unclear what is the effect of a weak interface or an interface with a soft layer, as is often the case in flexible electronics. For instance, plastic deformation in the thin film may trigger debonding of the interface, thereby allowing strain localization. Moreover, most free metal surfaces develop a native oxide which may also prevent dislocation movement to a certain degree, therefore, a highly compliant interface may reveal mechanical behavior closer to a truely unpassivated surface than a free metal surface with native oxide.

To test these hypotheses, in the present research, a range of three-layer membranes consisting of $\mathrm{SiN} /$ polymer/Cu and $\mathrm{SiN} / \mathrm{Cu} /$ polymer stacks have been manufactured for testing in the bulge test apparatus. The $\mathrm{SiN}$ layer is always present in the stack to be able to drive the Cu layer into compression, while a range of polymer films with different hardness applied by a spin coating process is added to create a set of $\mathrm{Cu}$ interfaces with varying compliance. Particular care has been taken to assure that the $\mathrm{Cu}$ film at the $\mathrm{Cu}$-polymer interface is not oxidized. The bulge tests are scheduled to be executed in the upcoming months and the resulting stress-strain curves of a $\mathrm{Cu}$ film adhered to compliant substrates will be compared to the stress-strain curves of (the same) $\mathrm{Cu}$ film in a freestanding and fully-passivated configuration. Emphasis will be on differences in the Bauschinger effect and in the flow stress [see Fig. 1(b)], while the evolution of the microstructure may be measured with transmission electron microscopy. The results promise to yield new and detailed insight into the plasticity of thin metal films found in flexible electronics applications and will be used to formulate an (extended) model of the dislocation dynamics at (weak) interfaces.

\section{References}

1. Hutchinson, J.W. and Suo, Z., Advances in Applied Mechanics, vol. 29, 63-191, 1991.

2. Xiang, Y. and Vlassak, J.J., Scripta Materialia, vol. 53, 177-182, 2005.

3. Xiang, Y., Chen, X., and Vlassak, J.J., Journal of Materials Research, vol. 20, 2360-2370, 2005.

4. Xiang, Y., Li, T., Suo, Z., and Vlassak, J.J., Applied Physics Letters, vol. 87, 161910, 2005. 